\title{
DEVELOPMENT OF THE TARGET PROGRAM IN THE INSTITUTION OF GENERAL SECONDARY EDUCATION REGARDING THE MANAGEMENT OF THE PROCESS OF FORMATION OF BUSINESS QUALITIES OF SCHOOLCHILDREN
}

\section{Liliia Martynets}

The most effective in the first problems of managing lighting systems in the first place is the program-centralized input. In the paper, the last steps of the school curriculum are discovered and the process of shaping the school curriculum is controlled. In general, the development of the whole program with clearly defined goals, objectives, predicted results, which is balanced with personnel and minds, obvious resources, is necessary. In the statistics, it is indicated, that the main program is intended for such goals: it is directed to the forecast of changes, updating the effectiveness of the foundation of the development and implementation of the strategy of development; it can make innovations straightforward, ensures the systematicity of the processes in the implementation of the innovation; works on the mission of the school, laying foundation for the image.

The approximate structure of the program is determined: substantiation of the problem; theoretical and methodological foundations; the purpose and objectives of the program; stages of program implementation; measures for the implementation of the program; Expected results; analysis and evaluation of the results of the innovation program.

It is established, that the development of the program has the following support: organizational support of the program modernization of the working curriculum in accordance with the conceptual objectives of the institution; regulatory and legal support of the program - adjustment of the package of documents: development programs of the educational institution; target programs, regulations; scientific and methodological support of the program - theoretical substantiation of the subject of experimental research work; creation of a diagnostic complex for studying the personal sphere of pupils; organization of seminars, pedagogical consultations, scientific-practical conferences as effective means of directing selfeducational activity of teachers on improvement of own experimental-research competence; development of special courses, focused on the formation of business qualities of pupils; material and technical support of the program - improvement of development of a methodical office; creation of a media cabinet; expansion of the school library fund, use of Internet opportunities, etc.

Keywords: program-target approach, management, target program, innovative orientation, strategic goal

(C) The Author(s) 2021

This is an open access article under the Creative Commons CC BY license hydrate

How to cite:

Martynets, L. (2021). Development of the target program in the institution of general secondary education regarding the management of the process of formation of business qualities of schoolchildren. ScienceRise: Pedagogical Education, 4 (43), 31-35. doi: http://doi.org/10.15587/25194984.2021.238026

\section{Introduction}

Solving the problem of forming business qualities of pupils requires the modernization of many components of the educational system, which can either destroy the entire system, or, if there are effective management tools, to bring the system to a qualitatively new level. Note also that the readiness of a school principal is no less important in this regard.

The problem of readiness of leading pedagogical workers of an institution of general secondary education for experimental work is extremely actual and important. This is the solution of many issues: improvement of the system of advanced training of leading pedagogical workers; fuller and more effective satisfaction of their professional needs and demands in the system of methodical work; identifying the strengths of the head, in planning ways and specific means of their consolidation and development in the individual style of management teaching activity.

Success in improving professional skills of teachers largely depends on the level of professionalism of the management team of a general secondary education institution. The existence of a team of like-minded people at school means a vision of all the defining strategic goals and objectives of the educational process. If the activity of the administrative team, teachers will be purposeful, coordinated, information-provided, professionallyperfect, it will provide a high effect in achieving the goals [1].

The head of a modern Ukrainian school should become a manager in the field of education: be able to independently determine strategic goals and objectives of 
management, to develop detailed plans to achieve these goals, to decompose problems into specific tasks, to coordinate educational institutions with other ones, to constantly improve hierarchical structure, to optimize admission procedures, to make management decisions, to search for the most effective management styles of the team and to improve the motivation of employees.

\section{Literary review}

Since the late 80 's of XX century the problem of formation of business qualities of schoolchildren receives recognition as a subject of research and pedagogical experience. In scientific works of recent years, it is said, that it is time to scientifically ensure the process of educating business people.

A special role in shaping business qualities of an individual is assigned by an American researcher J. F. Gilmore. A business person, according to J. F. Gilmore, is a person who shows a creative, innovative approach to solving life's problems. It is characterized by responsibility in relationships with other people, independence and perseverance. The scientist believes that the degree of formation of business qualities of an individual is determined by how skillfully the individual copes with life situations [2].

German researchers Berbel and Heinz Schwalbe claim: "To succeed, you need to be able to manage yourself" [3]. Therefore, maintaining his/her constant growth and development becomes a necessity for every business person.

To study the essence of the research problem, in our opinion, the concept of personal and business potential of a person is important, which is substantiated in the work of a researcher of a neighbor country S. Grinshpun [4]. The author considers personal and business potential as a combination of qualities and competencies of a business person. This potential allows individuals to assess their own resources, to choose the scope of their abilities, to mobilize readiness to organize their own business in conditions of competition and possible unemployment.

Theoretical and practical aspects of educating certain qualities of a business person in pupils are presented by the results of modern Ukrainian researchers. This is, first of all, the research of V. Kremen, devoted to the development of rationality as an activity phenomenon of schoolchildren [5]. The formation of pupils' assessment qualities is considered in combination with the acquisition of analytical and synthetic skills. In particular, a young person should know not only the criteria for analysis and evaluation of a particular activity, but also select them for a given situation. For this purpose, operations of analysis, synthesis, comparison, concretization, abstraction, generalization, classification, systematization, etc. are offered. During the gradual mastering of analytical-synthetic skills and abilities by pupils, "windows" of independent decisions, adjustments and hypothetical proposals are put into action. The zone of independent actions of pupils can change depending on the level of mastering the basics of logical operations.

Regarding the education of responsibility in young people as the main quality of a business person, the works of I. Bekh, V. Orzhekhovska, M. Savchyn [6-8] are considered fundamental. The scientists have focused on creating a moral socio-cultural environment, when a pupil is seen in a multi-role position as a growing individual and citizen. For its emotional saturation, life situations with a moral meaning that reflects the reality, surrounding pupils, are widely used.

N. Chaban's views are of some interest for our research [9]. The researcher believes that the internal reaction of a business person to the external reality is due to the presence of qualities that characterize his/her moral and rational-pragmatic orientation. Sufficient to characterize the essence of a business human with morally oriented behavior, says N. Chaban, are three qualities - responsibility, organization and practicality. Z. Hipsters emphasizes that anyone can be considered a business person, regardless of their age, gender, education, social status, professional activity. Training of future specialists, according to the author, is to educate a creative person with high education, culture, morality and spirituality, business development, practical orientation [10].

Y. Kalugina notes that a modern specialist must have a certain set of qualities: competence, ability to organize and plan, independence, willingness to make decisions and be responsible for them, the ability to identify rational ways to implement decisions in practice, make timely adjustments, taking into account realities of surrounding circumstances [11]. Honesty, fairness, and perseverance are essential. A real business person, the researcher notes, is highly educated and highly aware, attentive to problems of his/her business partners, reliable in all respects.

Thus, scientists study the business qualities of an individual, emphasize the importance of educating these qualities for successful activities. However, despite the variety of approaches to the formation of the qualities of a business person, outside the scientific interests of researchers is the process of management and development of a targeted program in general secondary education. Thus, the urgency of the problem led to the choice of research on the development of a targeted program in general secondary education to manage the process of forming the business qualities of pupils.

\section{Research aim and tasks}

The aim of the article is to determine the main steps of a school principal to manage the formation of business qualities of pupils.

To achieve this goal, the following tasks were set:

1. To highlight and analyze the results of the questionnaire on the establishment of management practices in the process of forming the business qualities of pupils in general secondary education.

2. To identify the steps of a school principal to manage the formation of business qualities of pupils.

\section{Materials and methods}

In accordance with the tasks and objectives, the following research methods were used: theoretical: analysis, generalization of scientific, philosophical, psychological and pedagogical works of Ukrainian and foreign authors on research; empirical: questionnaires to determine the practice of managing the process of forming the business qualities of pupils.

With the help of analysis the problem of formation of business qualities of a person, value of this 
process in formation of a pupil as a business person was investigated. The method of analysis also provided an opportunity to summarize the results of the survey on the management of the process of forming the business qualities of pupils in general secondary education. Using the method of questionnaires allowed to find answers to the respondent's questions and to provide quality information for the analysis. The generalization method was used to form conclusions.

\section{Research results and their discussion}

In pedagogical theory and practice there is a lack of scientific-theoretical and organizational-methodological aspects of preparing the head of a school to manage the formation of business qualities of school pupils.

In order to study the pedagogical practice of managing the process of formation of business qualities of schoolchildren in general secondary education institutions, a survey of heads of 270 educational institutions of Donetsk region was conducted on the following issues:

1. Do you think the problem of forming the business qualities of pupils' personality is relevant for a modern general secondary education institution?

2 . Is the problem of forming the business qualities of a person a priority in your educational institution?

3. What methods and forms of work on the formation of business qualities of an individual you use in the practice of your institution?

4. What business qualities are formed in the educational process of your institution?

5. Do you consider the work on the formation of business qualities of an individual in your institution systematic and purposeful? participants.

Informational consent was obtained from all study

As a rule, the questions have a sufficient number and it is determined based on the required depth of discussion of the questions that are imposed on the respondents.

During the analysis of the results of the survey of heads of educational institutions it was found that:

$-65.9 \%$ of managers consider the problem of forming the business qualities of pupils' personality relevant for a modern general secondary education institution; $34.1 \%$ of managers partially agree with the urgency of the problem;

- for $79.6 \%$ of institutions the problem of formation of business qualities of a person is a priority task, but this problem does not act as a mission for educational institutions;

- for the formation of business qualities of an individual in the practice of the institution modern methods and forms of work are used, namely: participation in the implementation of international and regional projects, programs $(63.7 \%)$; teaching electives and special courses $(56.7 \%)$; popularization of business organization technology (16.2\%); implementation of social partnership, creation of a system of support for international relations $(13.9 \%)$;

- to the question "What business qualities are formed in the educational process of your institution?" managers listed the following qualities: business acumen, creativity, activity, entrepreneurship, efficiency, initia- tive, erudition, purposefulness, enthusiasm, responsibility, willingness to take risks, competence, organization, communication, etc.

$-28.5 \%$ of managers consider the work on the formation of business qualities of an individual in their institution systematic and purposeful.

It can be noted, that in general secondary education institutions some experience has been gained in the formation of business qualities of schoolchildren. Recognizing the urgency of this problem, many teaching staffs use various modern methods and forms of work to solve it. However, in most cases, purposeful and systematic work on the formation of high school pupils' business qualities in educational institutions is not carried out.

Step 1. Creation of a motivational environment in the educational institution - the formation of a special mood of all staff: pedagogical, technical, pupils and their parents on the formation of business qualities of pupils is the most important condition and guarantee of a positive outcome of the planned activity.

Step 2. Problem analysis of the state of the educational system - construction of the "problem field" and determination of how the problem of formation of business qualities of schoolchildren is correlated with other problems of the educational institution; what problems of the educational institution contribute to the solution of the main problem, and how the solution of a certain problem affects the solution of other ones.

The choice of this path determines the development of a targeted comprehensive program "Formation of business qualities of pupils", which is the result of modernization of management through a program-targeted approach.

The target program is a system of activities with clearly defined goals, objectives, projected results, which is balanced with personnel and other conditions, available resources and meets the following characteristics [12]:

- aimed at forecasting changes, updating the activities of educational institutions and developing development strategies;

- has a clear innovation orientation, provides a systematic process of innovation;

- works on the mission of the school, creates the image of the institution.

The approximate structure of the program is as follows: substantiation of the problem; theoretical and methodological foundations; the purpose and objectives of the program; stages of the program implementation; measures for the program implementation; expected results; analysis and evaluation of the results of the innovation program.

Step 3. Formulation of goals and definition of tasks - construction of a "tree of goals" in accordance with the "problem field"; involves prioritizing existing problems.

Realization of the strategic purpose - formation of business qualities of schoolchildren - consists in its obligatory decomposition (division of the purpose into components): to form the conscious relation of a person to the professional life; to promote the formation of pupils' ethics of conversation between business people, the ability to build business contacts; stimulate the desire for cooperation; to develop life skills of self-management; to form intellectual, special and general cultural knowledge 
and skills of pupils on design technology; learn to see problems and make decisions, develop the ability to draw sound conclusions; to develop the ability to plan, receive and use information, based on knowledge of facts, laws of science, the ability to learn independently; to develop the ability to resolve conflicts in a team, to resolve natural contradictions in non-conflict ways: through cooperation, compromise, concession; to develop pupils' presentation skills [13].

Step 4. Drawing up an action plan - forecasting and planning specific management actions for the implementation of goals and objectives with the definition of deadlines and performers.

The development of the program has the following support:

1. Organizational support of the program - modernization of the working curriculum in accordance with the conceptual objectives of the institution.

2. Regulatory and legal support of the program adjustment of the package of documents: development programs of the educational institution; target programs, provisions.

3. Scientific and methodological support of the program - theoretical substantiation of the subject of experimental research work; creation of a diagnostic complex for studying the personal sphere of pupil; organization of seminars, pedagogical consultations, scientificpractical conferences as effective means of directing selfeducational activity of teachers on improvement of own experimental-research competence; development of special courses, focused on the formation of business qualities of pupils.

4. Logistics of the program - improving the development of a methodical office; creation of a media cabinet; expansion of the school library fund, use of Internet opportunities, etc.

Step 5. Preparation of the school staff for experimental work on the formation of business qualities of pupils.

Activities to prepare teachers for experimental work on the formation of business qualities of pupils are implemented through various modern forms of work: traditional and non-traditional, collective and individual: lectures, seminars, round tables, debates, business and roleplaying games, solving pedagogical situations, participation in scientific-practical conferences, trainings, etc.

As part of the preparation of managers, teachers for the future experiment, a course of lectures and seminars on the following modules: "Philosophy of Education: relevance and prospects", "Design as a mechanism of self-development and the institution of self-realization of subject of the educational process", "Theory and methods of business qualities of pupils", "Project activities as an important aspect of pupils' competence education", "Conflict management strategies", "Innovative educational technologies", etc is required. These classes help to restore, systematize and update the scientific and methodological knowledge of teachers, to form a single conceptual apparatus, to master the theoretical basis of the problem of forming the business qualities of pupils and the necessary methodological tools [13].

Improving the professional competence of managers, teachers can be done through specially designed special courses, such as "To the top of skill". The main goal of the program is to help teachers to master the minimum of pedagogical knowledge on creating their own image of a business woman-teacher, to improve the technology of creating projects on the theoretical, practical and creative levels. The program has the following sections: "Image of a business woman-teacher", "Success map of a business woman-teacher", "To professional competence - through the method of projects", "Professional teacher's workshop".

The effect of parents' influence on children largely depends on how well they have a need to raise children, how much they have the appropriate psychological and pedagogical knowledge, how closely they work with the school. To this end, in the educational process of secondary school it is advisable to introduce the program "Family education: the formation of the living space of the individual":

Section 1. "Child: the process of its development and raising conditions."

Section 2. "Pedagogy of cooperation between teachers and parents - an important condition for raising a child."

Section 3. "Fundamentals of choosing a profession."

Section 4. "Teach and educate."

Effective in forming pupils' needs for the development of business qualities, establishing themselves as a business person is their acquaintance with the biographies of prominent business people of the world, consideration and analysis of characteristics, situations, facts from their lives. Valuable information material about the lives of business people is contained in the media (magazines, newspapers, television, radio, etc.). Among the large number of information sources, we can offer not only pupils but also teachers and parents to get acquainted, select media that contain the necessary materials on professional and social activities, as well as the private lives of famous representatives of the "business world".

In addition, pupils can be recommended to watch TV projects on their own, followed by a collective analysis of the information obtained. Among the available TV programs are the following: programs from socio-political and public life; economic programs; transfer of legal orientation; entertainment, music, cognitive projects.

Introduction a special course "Business human: ways of becoming" to the curriculum of high school pupils helps to learn the ways of becoming a business human, the possibility of continuing education and obtaining a profession [13]:

Section 1. Fundamentals of business psychology.

Section 2. Features of the strategy of selfdevelopment of a business person.

Section 3. Secrets of communication.

Section 4. Organization of professional activity of a business person.

The conducted work promotes: coordination of actions of participants of the experiment; stimulating innovative activity of teachers; creating a positive microclimate, which is necessary for productive cooperation.

Step 6. Monitoring of intermediate results - collection of information on the condition and development of monitoring objects; involves determining the purpose 
and objects of monitoring, determining the criteria, on which basis of the state of the object will be determined, determining the reference value of the criteria, quantitative and qualitative characteristics of the results, establishing a pedagogical diagnosis.

Step 7. Analysis and evaluation of the results of the program "Formation of business qualities of pupils" - a summary of the results of work, involves obtaining information about the results of the organization and conduct of the experiment. The activities of teachers and managers at this stage are aimed at evaluating the results, obtained using various diagnostic techniques, comparing the results with the goals, drawing conclusions about the relationship of the chosen goal and objectives with the results; determining the effectiveness of the work on the basis of logical analysis; making management decisions.

Thus, the purposeful and systematic work on the formation of high school pupils' business qualities in educational institutions allows managers to clearly focus on the goals; identify appropriate tools for achieving goals; to develop a system of step-by-step evaluation of the achievement of goals; focus on the goal as a criterion for achieving results. The disadvantage of this study can be considered insufficient preparation of school principals for this process. This may be the subject of further research.

\section{Conclusions}

1. The study presents the results of the questionnaire on the practice of managing the process of forming the pupils' business qualities in general secondary education. The vast majority of respondents note the problem of forming the business qualities of pupils' personality relevant to the modern institution of general secondary education. However, they consider this work in their institution unsystematic and unfocused.

2. The steps concerning management of formation of business qualities of schoolchildren were discovered: creation of the motivational environment in an educational institution; problem analysis of the state of the educational system; formulation of goals and definition of tasks; drawing up an action plan; preparation of school staff for experimental work on the formation of business qualities of pupils; monitoring of intermediate results; analysis and evaluation of the results of the program "Formation of business qualities of pupils".

Thus, the question of preparation of a head, school stuff for experimental work has the huge value for the further development of an educational institution. The program-targeted approach makes it possible to trace the main steps of a school principal to manage the formation of business qualities of pupils.

\section{References}

1. Martynets, L. (2020). Project technology implementation for development of business qualities in senior pupils. Journal of Critical Reviews, 7 (11), 891-895. Available at: http://dspace.lgnau.edu.ua/xmlui/bitstream/handle/123456789/2163/197-1592986403. pdf? sequence $=1 \&$ is Allowed $=y$

2. Pomelov, V. (1988). Vospitanie delovykh kachestv u shkolnikov. Moscow: O-vo Znanie, 48.

3. Shvalbe, B. (1993). Lichnost, karera, uspekh. Moscow: AO Izdat. gruppa Progress-Inter, 228.

4. Grinshpun, S. (1998). Lichnostno-delovoy potentsial shkolnika. Shkola, 5, 25-31.

5. Kremen, V. H. (1999). Ratsionalnist yak diialnisnyi fenomen shkoliara. Uchytel, 11/12, 46-51.

6. Bekh, I. D. (1994). Vidpovidalnist osobystosti yak meta vykhovannia. Pochatkova shkola, 9/10, 4-8.

7. Orzhekhovska, V. (1996). Formuvannia sotsialnoi vidpovidalnosti uchniv u suchasnii shkoli. Pedahohika i psykholohiia, 4, $25-32$.

8. Savchyn, M. V. (1993). Problemy vyvchennia vidpovidalnosti yak sotsialno-psykholohichnoi yakosti liudyny. Pedahohika i psykholohiia, 4 .

9. Chaban, N. I. (2003). Formuvannia moralno-volovykh yakostei dilovoi liudyny u starshoklasnykiv. Kherson, 170.

10. Hipters, Z. (2005). Vykhovannia dilovytosti i tvorchosti maibutnikh fakhivtsiv ekonomichnoho profiliu. Ridna shkola, 12, 49-51.

11. Kaluhina, Yu. (2006). Problemy formuvannia moralno-etychnykh tsinnostei u fakhivtsiv finansovo-ekonomichnoho profiliu. Dukhovnist osobystosti: metodolohiia, teoriia i praktyka, 6 (19), 70-74.

12. Morse, J. (1999). The Missing Link between Virtue Theory and Business Ethics. Journal of Applied Philosophy, 16 (1), 47-58. doi: http://doi.org/10.1111/1468-5930.00107

13. Martynets, L., Stepanchenko, N., Ustymenko-Kosorich, O., Yashchuk, S. et. al. (2020). Developing Business Skills in High School Students Using Project Activities. Revista Romaneasca Pentru Educatie Multidimensionala, 12 (4), 222-239. doi: http://doi.org/10.18662/rrem/12.4/343

Received date 11.05.2021

Accepted date 08.06.2021

Published date 30.07.2021

Liliia Martynets, Doctor of Pedagogical Sciences, Professor, Associate Professor, First Vice-Rector, Department of General Education, Luhansk National Agrarian University, Slobozhanska str., 68, Starobelsk, Ukraine, 92703

E-mail: liliamart7@gmail.com 